\title{
The London killings of 2018: the story behind the numbers and some proposed solutions
}

\author{
Sue Roberts ${ }^{1}$ \\ Published online: 1 April 2019 \\ (c) The Author(s) 2019
}

\begin{abstract}
This paper examines the underlying issues behind the London killings of 2018 and considers some possible solutions. To do this, primary research has been undertaken with those involved in the violence, those charged with addressing it and those seeking a solution to this crisis. Violence among young people in the capital and elsewhere in Britain has been the focus of much media attention and academic discourse, some of which are examined here. In understanding the causes of the violence, it is, however, incumbent on us all to consider viable ways in which to address the issues behind the killings and identify possible solutions to the problems it creates in communities. The introduction, in January 2019, by the present Home Secretary of knife crime prevention orders appears to have aggravated the situation. Already known as Knife ASBOs (Guardian in Knife ASBOs won't cut crime, but the will harm vulnerable young people, https://www.theguardian.com/commentisf $\mathrm{ree} / 2019 / \mathrm{feb} / 01 / \mathrm{knife}-a s b o s-c r i m e-y o u n g-p e o p l e-s a j i d-j a v i d, 2019)$, these may simply criminalise a group of youngsters, sometimes as young as 11 or 12 . Police are already able to tackle criminal behaviour among youngsters carrying knives through dispersal orders. This response by the Government has not addressed the root causes of the issue. As one respondent was to state:
\end{abstract}

We have to find a way through this. It's killing us. Not just the kids who are killed: it's the people that get left behind. Something must be done to stop it. (R: 16, 13 November 2018)

Keywords Knife crime $\cdot$ Partnership working $\cdot$ Multi-agency $\cdot$ Policing $\cdot$ Community safety

Sue Roberts

sue.roberts@port.ac.uk

1 School of Area Studies, History, Politics and Literature, University of Portsmouth, Portsmouth, UK 


\section{Background}

During 2018 there were over 100 murders in London, most related to gun and knife crime (McVie et al. 2018). Across political media and academic discourse, there has been exceptional interest in these murders. In November 2018 the BBC reported 123 murders during the year with over seventy stabbings as part of that figure (BBC News 2018a). Yet the media focus on violent crime among young people in London has ignored the fact that conceptual, theoretical and empirical tools available to academics studying the social and political aspects of the murders leave them well placed to help unravel this complex issue. It may also enable them to identify some possible solutions. This paper provides an exploration of the empirical evidence that lays behind the violence, throwing light on the social factors that underpin it while also offering insights into possible remedies.

One of the great weaknesses in the academic literature is reflected in Fussey and Richards' 2008 paper which highlights the lack of primary evidence in the field (p. 37). It is suggested that the strength of the research in this paper is its use of primary sources to examine the complex issues that comprise the conceptual and empirical story behind the growing number of victims. Participants were recruited through professional contacts in services and through operational contacts in the field. In using primary research, this paper identifies hitherto underreported issues in the literature regarding the drivers of violence. Significantly it also considers how the violence can be confronted.

\section{Research design}

The primary research necessary to provide the back story to the media reports and academic commentary began as the focus of this paper. Because the killings include perpetrators, victims and the communities from which they originate, it was deemed important to the rigour of the research to include as wide a range of those involved as possible. Over 9 months (April and December 2018), the researcher interviewed 8 young people in a single group interview (because none gave permission to be individually identified), 1 gang member, 1 former gang member and prisoner, 2 prison officers (from Pentonville and Belmarsh prisons), 2 youth workers, 3 serving police officers, 1 PCSO, 1 former probation officer, 1 community safety officer, 2 local authority community development workers and the Director of the Scottish Violence Reduction Unit. The researcher also attended several meetings involving multi-agency community safety partnerships (established as Crime and Disorder Reduction Partnerships under the Crime and Disorder Act 1998). Participants for the research were selected for their close links with and intimate knowledge of the violence, and in seeking to address it. At the same time there is also a human dimension to this research. In many instances, especially among the younger participants, location and identity have been protected due to serious concerns about retaliation. Interviewees are referred to by "R" (for respondent) and the interview number, followed by a colon and the date of the interview. 
The London killings of 2018 were shocking to the public and the impact will be felt in victim communities for many years to come. As one respondent noted:

I can't never forget this. I watched him die. I can't forget it; not me, not my family, not no one I know. (R: 14, 30 July 2018)

Another respondent was to state in relation to this:

This is something that we will live to regret, the death of youngsters like this. It's not going to get any better all the time there's no money for youth services. I can't sleep at night thinking of the kids I've known and lost in this community (R: 7, 18 August 2018).

Along with primary research, the paper makes use of secondary material. This is because both documentary and narrative analyses help elicit a richer picture of causative factors as perceived by those working and living within violent communities in London. A post-positivistic paradigm was therefore adopted. The researcher believes that human behaviour is neither fixed nor unchanging and at the same time, can be interpreted through the knowledge and background of the researcher. Responses to the violence can change in meaning and intent depending on the context. (Wisker 2007, p. 64). This research is exploratory by raising questions about what those involved thought of the violence. Data analysis has helped to establish why these thought processes arose and, more importantly, what solutions might be available. To achieve this, the research engaged with as varied a sample as possible. These included interviewees who were and are directly involved to those at a greater remove from the epicentre of the crisis in London but who yet had a valid range of experience to enable them to provide possible solutions. To achieve this, a broad-based questionnaire was devised to engage with three basic themes. These are identified below.

1. Participants' view of the causes of the violence

2. Participants' experience of the outcomes

3. Participants' views about possible solutions

These three themes were distilled from preliminary conversations at a large community meeting in Portsmouth during May 2018. This "Community Conversation" was organised by Portsmouth City Council and included 70 representatives of statutory and community services. The conversations which the researcher undertook at the meeting provided data on emerging themes among professionals and communities regarding the killings. The themes were also discussed with two youth workers and an MPS police officer to ascertain their suitability for a semi-structured questionnaire. This was subsequently undertaken through face to face and telephone interviews, with the transcripts recorded and analysed for keywords and phrases. Keywords and phrases were identified through frequency, but as with most qualitative research projects, much more emerged during the interviews that had not been anticipated. For example: the group of youngsters (I: 14, 30 July 2018) talked at some length about gaming and online "likes" to establish their popularity, and how 
this appears to have become linked to the actual killings. None, however, admitted to having done this themselves.

The interviews were identified as the appropriate method as the researcher needed to achieve a sufficiently nuanced understanding of the social realities in communities, individuals and cultures, through the subjective experiences of the people involved. Identities were protected both during the research process and in storing the data due to serious risks to respondents. These risks to participants were accounted for by ensuring that interviews were conducted anonymously and through intermediaries, both where appropriate and where requested. Where participants requested that their identity was withheld, this has been respected. This was deemed especially important for the young people who participated who were concerned that both their identities and exact locations should be protected.

There appears to be little doubt that those living and working among communities are acutely aware of the social realities of the violence and the contributory factors that generate it. They also have clear views about the means to end it.

The research demonstrates that the killings are in fact related to complicated social problems. Indeed, qualitative research techniques as deployed for the semistructured interviews in the research helped to bring that complexity to the fore (Cresswell 2014, p. 15). As was argued by one respondent

There is no single cause. It's a much higher problem, if you like, than that. None of this can be narrowed down to a few drivers in society as a whole. (R:

15, 12 November 2018).

Indeed, the rise in gun and knife crime in UK cities has prompted those in authority to seek to understand that complexity. London Mayor, Sadiq Khan announced, for example, that he will adopt the approach developed by the Scottish Violence Reduction Unit to combat the violence in London (BBC 2018b). The Government has also recently published The Serious Violence Strategy (HM Govt. April 2018) to address the issue by way of multi-agency or partnership working. It is fair to say that the levels of complexity relating to gun and knife crime far exceed a single, isolated cause. This may encompass the loss of police personnel, or the influence of "Drill" music, for example. However, one significant finding of this research relates to the need to include the locality in identifying any solutions to the violence. Local people should be involved and fully engaged in developing a joint response. As argued by one respondent:

It has to be people that have grown up around here and know the people in the area. Strangers dropping in won't cut it. It's an issue of trust. Without that you haven't got a hope. (R: 17, 14 November 2018)

This approach was supported by those who took part in interview 14 . They identified the need for intervention and participation by those who understand the issues faced by local communities rather than professional advice from outsiders. Dr Gary Slutkin, who initiated the original epidemiological approach to tackling violence in communities supported this view. When he returned from an extended period in Uganda to his home town of Chicago, he was shocked at the levels of violence 
experienced by young people. The spread of that violence reminded Slutkin of his experiences in Uganda and the containment of epidemics such as Aids. It was he who pioneered the approach later taken up by the WHO and the Scottish VRU. Slutkin used preventative tactics in Chicago as he had in Uganda "he recruited former gang members to educate current gang members, intervene in disputes and hopefully prevent the violence at source" (BBC News 2018f). It is a familiar and common sense method among community development workers (R: 17, 14 November 2018). At the same time, multi-agency partnership and collaboration remain a keystone to any structured response to the ongoing London killings. As was stated by one respondent:

There is no one solution that's going to put things right, no single person, or policy or thing that can make it right. Somehow we've all got to work towards it and I mean the communities, the councils, the government, the police, the schools. (R: 11, 20 June 2018)

\section{Collaborative working and the Scottish Violence Reduction Unit (VRU)}

Interviewees for this paper referred to the pressing need for collaborative working between communities and statutory agencies including Health, Police, Education Community Safety. They also stated that local people needed to address the violence. They argued that complex problems required joint solutions. A multi-agency approach offers a varied perspective that can help implement possible solutions. Respondent 13 identified a young person who had experienced violence and had problems at school and at home. This respondent was also subject to bullying, racism, isolation, social exclusion and also contacts with gangs. Acts of violence which may have been experienced by the respondent and his friend are not the only issue. A number of problems such as those identified above may accompany it.

The value of a partnership approach is acknowledged in the Serious Violence Strategy which places "communities and local partnerships at the heart of our approach" (HM Govt. 2018, p. 7). This is an important distinction. The engagement with affected communities is vital, as are statutory agencies and multi-agency groups in addressing the issue. One chapter of the Strategy document is in fact directed entirely to the central importance of a partnership approach. It is argued that only through what the strategy calls "multi-strand" (p. 70) joint action that progress can be made, and this includes engagement with communities. (HM Govt. 2018)

\section{The Scottish Violence Reduction Unit (VRU)}

The Violence Reduction Unit in Scotland has advanced a radically new approach to addressing serious violence in the major cities. It treats it as a public health issue and refers to violence as "a disease" (VRU 2018). This too involves a collaborative response including working with many partners. The VRU team itself is comprised 
of people from many different walks of life (VRU 2018). Most significantly, their approach has seen a drop in the rate of violence to zero during the same period covered by this research. It has also attracted the attention of other police forces in England.

The VRU came into being in 2005, partly funded by the Scottish Government, and describes itself as a "centre of expertise in tackling violence" (VRU 2018). Glasgow had been identified as one of the most violent cities in Europe with 41 deaths in the city recorded in 2005. Since its establishment in 2005, violence has steadily decreased with homicides falling to their lowest levels since 1976 (VRU 2018). It is important to note that the information given by the VRU points out its many links with partners across all agencies. The approach is not one solely undertaken by the police. Instead a partnership operates with the VRU. This starts with what the VRU call their "Navigators" in accident and emergency departments who are able to identify victims upon admission to hospital. To tackle the violence, they also work with a Social Enterprise company, liaise with ex-offenders as well as a range of other partners across many different agencies.

The VRU's approach was heavily influenced by the World Health Organisation's 2002 Report on Violence and Health (WHO 2002) which in turn recognised Slutkin's work in Chicago during the late 1990s. This established a link between violence and public health. The report considered the issue globally and explored the link with public health. Yet just as important, it argued that the approach to the problem was interdisciplinary

The public health approach to any problem is interdisciplinary and sciencebased. It draws upon the knowledge from many disciplines, including medicine, epidemiology, sociology, psychology, criminology, education and economics (p. 3).

This is significant because the multi-agency approach is recognised in the diagnosis of the problem. The report goes on to recognise that:

the serious, immediate and future long-term implications for health and psychological and social development that violence represents for individuals, families, communities and countries (p. 3).

This links violence in communities closely to the physical, social and psychological health of residents. It is this method that the Scottish VRU has sought to emulate. Moreover, Linden (I: 15) of the Scottish VRU was to note that multi-agency partnerships (MAPs) are of themselves not able to address the violence alone. Partnerships can tackle particular local issues, but the communities themselves, he said, needed to be encouraged to identify any solutions. As he argued:

Multi-Agency Partnerships can't do this on their own. The communities themselves have to drive the whole thing. Yes, MAPs can concentrate on aspects of problems in communities and on small groups, but day to day, you have to get the communities on board with an active role in changing what's going on. (R: 15, 12 November 2018) 
This view is reflected to some extent in the current academic discourse. One example would be Cohen whose publication "Communities can prevent violence" in 2017 appeared before the latest spate of murders in London. He argues that promoting health is closely associated with preventing violence in communities. He highlights the parallels between health and reducing violence:

Education, strong social networks, and norms that support healthy relationships all protect against violence. People need access to jobs and education, as well as a sense of feeling safe and welcome in their environment to walk in their neighbourhood, engage with their neighbours, or let their children ride bicycles in local parks. Those who are safe in their environments are more likely to have strong social networks.... (Cohen 2017)

The evidence from this research shows that youngsters in London lack strong social networks outside their immediate "gang" or group. This is exacerbated through the isolating experience of online social media in which young people spend time alone interacting with a virtual group of friends rather than with real-life groups. Using social media, youngsters interact with virtual groups of friends. It is also noticeable in the way that many young people now report a sense of isolation, of not belonging, and in some cases being actively pushed out of their communities. As one respondent was to state:

If you're black and you got no money and no like job, they want us out of London. Out or dead. It's like that at school too you know. School's hostile, you know? They don't want us. Black kids and school, they don't go. (R: 10, 12 June 2018).

Collaborative working can certainly help in combating isolation and social exclusion. However, communities themselves should also be involved and must take the lead to combat the violence. Respondent 10 provides a clear understanding of what it means to feel isolated and alone, on the edge of society. He commented:

Look, its like, no one gives a shit no more. Not police, not no one.

(R: 10, 12 June 2018)

Partnership working and multi-agency groups have in fact been used to address difficult or complex issues by local government and statutory agencies for many years (HM Govt. 2000, part 1, section 4.3; Balloch and Taylor 2001). Such partnerships include the Community Safety Partnerships. Given the complexity of social issues, a structured approach to analysing the data is needed and this relates to four overriding issues identified by the interviewees. These are:

1. Government cuts to policing

2. Government policy of austerity and its effects in local areas

3. Housing

4. Cuts to youth services 
These were identified through the frequency of occurrence in the questionnaires. Housing was mentioned 55 times, cuts to policing 49 times and cuts to local services 43 times.

\section{Government cuts to policing}

There is little equivocation about the extent of cuts to policing and community safety since 2010/2011. National Audit Office figures (Comptroller and Auditor General 2001 , p. 16) show that direct government funding for policing fell by $25 \%$ ( 22.3 Billion) over the years 2010-2016. The Institute for Government (2017) has published figures taken from the UK Home Office which charts a further drop in police funding and the concomitant fall in police numbers by $14 \%$ to 2017.

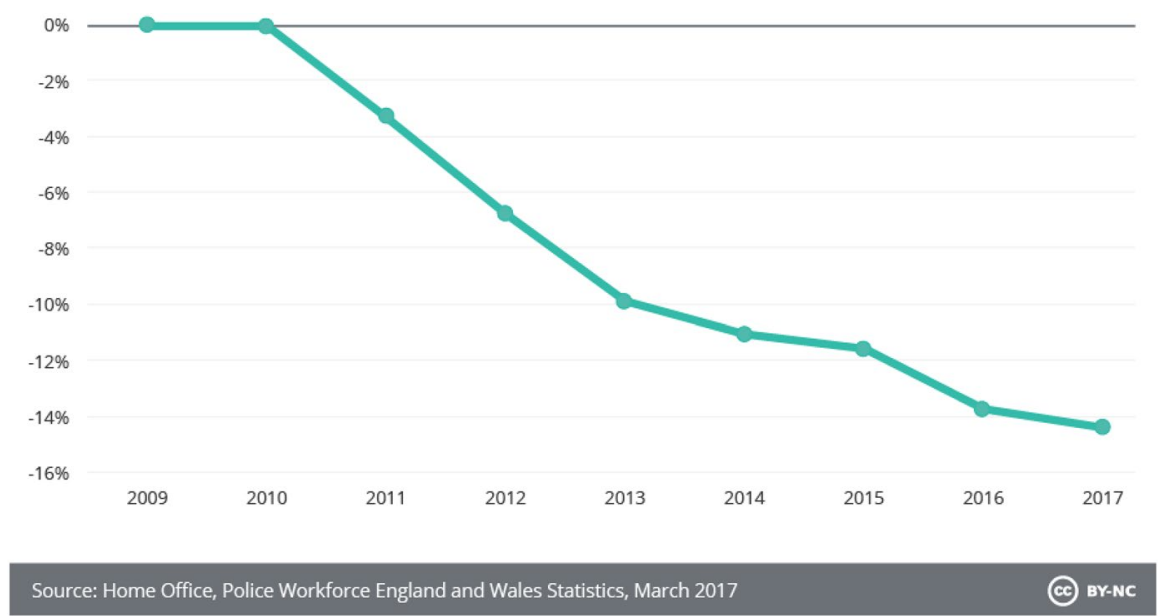

There is no question that police numbers have fallen and continue to fall, with a loss to date nationally of 21,000 police officers, 18,000 police staff and 6800 Police Community Support Officers (PCSOs) since 2010 by March 2018 (House of Commons Library 2018; Disney and Simpson 2017, p. 2). This equates to nearly onequarter of the police force for England and Wales. The House of Commons Debate Pack records concerns about the ability of UK police to maintain public security and community safety. These concerns are echoed by the Police Inspector and Community Safety staff respondents. They stated that:

It just won't be possible to go on like this. I've got just two police officers available at any one time to cover the whole of the north of my patch. It cannot get any worse without a complete lack of police officers for parts of my area. What does that say about my ability to keep people safe?

(R: 12, 8 April 2018).

Cuts to policing have also extended to the neighbourhood level. The loss of Police Community Support Officers (PCSOs) underlines the key importance of information 
from communities collected through the deployment of these police personnel. One police manager praises the value of information from PCSOs. He argued that:

...I will often be approached by a PCSO telling me that they have put " $\mathrm{X}$ " number of intelligence reports onto the system in a week and that they were all in relation to known offenders or a geographic hot-spot. These daily briefings that are delivered to response and proactive units across London every day are fed from these intelligence reports. The PCSOs take great pride in seeing their intelligence being disseminated to warranted colleagues. (Loveday and Smith 2015), p. 4).

Although PCSOs are not warranted officers, their neighbourhood work is of enormous value. Indeed, the Government's Serious Violence Strategy (HM Govt. 2018) rather ironically, highlights this using the example of increased PCSO patrols in Peterborough which is set out to illustrate the value of a targeted response to crime. In the light of this, it is interesting to note that the previous Metropolitan Police Commissioner (Hogan-Howe) intended to remove all PCSOs in the MPS area in response to the cuts (Loveday 2017a, b).

The importance of PCSO local intelligence was also highlighted in this research. Portsmouth City Council, Hampshire Constabulary, Surrey Police and the representative from the Metropolitan Police emphasised the key importance of PCSO neighbourhood policing and the intelligence from local communities that they generated to pass to warranted officers. If communities and local partnerships are at the heart of the Government's strategy to reduce serious violence (p. 7), it seems logical to retain and utilise those who maintain close ties with communities. Increased spending on the Police, it could be argued, should be directed to a substantial increase in PCSO numbers rather than that of warranted officers. Moreover, Linden's (R: 15) comment about communities leading the fight against serious violence must be sustained. PCSOs are best placed to achieve this and could play an integral part in mobilising and motivating the community while also working through statutory agencies. PCSOs work closely with community workers in local authorities and those responsible for community safety. As was suggested by one PCSO:

We are the eyes and ears for communities and the Police. We know our communities and the problems that they have. (R: 1, 22 April 2018).

Falling police numbers remain the focus of much attention in the UK media and professionals. The Metropolitan Police Commissioner, Cressida Dick, has appeared before the House of Commons Select Committee where he claimed that it would be "naïve" to think that the fall in police numbers had nothing to do with the rise in gun and knife crime in 2018 (Parliament TV 2018). The office of the London Mayor has also published figures in January 2018 revealing that $£ 600$ million had been cut from the Metropolitan police budget since 2010 (Mayor's Office 2018).

In October 2017, concerns about police numbers were expressed by the then MPS Deputy Commissioner (The Guardian 2017). Later the MPS Commissioner stated that police cuts had contributed to the rise in violent crime (The Guardian 2018a). 
No supporting evidence was, however, provided and the Home Office continued to argue that it was police deployment, not police numbers which remains crucial.

One question remains: to what extent are these statements supported by the facts? In 2017, the Institute for Fiscal Studies confirmed that 20,000 police officers were lost between 2009 and 2016 and further cuts to police funding were planned by the Government until 2020 (Disney and Simpson 2017, p. 3). The Association of Police and Crime Commissioners reported in 2015 that "Budget cuts will radically affect policing" (APCC 2015) stating that a "fundamental rethink" would be necessary to help maintain services. A compelling argument comes from Lumsden and Black's 2017 paper on austerity policing. Here they refer to Her Majesty's Inspectorate of Constabulary's (HMIC) warning about the impact of austerity on police forces in England and Wales. The study uncovered evidence of police "deliberately suppressing demand, not responding to crimes and not making arrests due to a lack of resources" (Lumsden and Black 2017, p. 60). If police are not making arrests due to lack of resources, it is likely that in cities such as London this may have reached the criminal community. Lumsden and Black's argument about police officers not making arrests does in fact coincide with a former gang member's statement. Here he warned of a "window of opportunity" for those seeking to perpetrate violent and other types of crime (BBC, April 4, 2018a, b). Furthermore, as former gang member interviewed for this study stated:

I know I ain't gonna get caught. They don't even bother to come out no more.

(R: 10, 12 June 2018)

Additionally, one respondent from Croydon who works with young people in the area stated:

For sure it's the gangs, but those gangs are doing their stuff because they can, right? The police just don't have the manpower to do much about it, and there's no real sanction because the police can't act. (R: 11, 20th June 2018)

This reinforces the significance of police interaction with the community and informs us that the significant decline in PCSO numbers may have come at great cost.

A former gang member was to argue that "Due to spending cuts there has been less policing, community centres are closing. There's been no money directed at the third sector for a while and with all these cuts and reductions we've got more young people falling out onto the streets" (BBC, April 2018a, b). This indicated that this is not merely a question of fewer police officers on the streets. A prison officer respondent stated:

These are kids who no longer have any support, either at home or in the community. There are very few youth workers of local services since the cuts to local authority budgets. They literally feel they are on their own and it's kill or be killed (R: 5, 2 June 2018)

A young former gang member supported this in his comment that: 
I got a knife because all the bad boys got one. I'd rather be arrested and sent to prison for having a knife and still be alive. If I didn't, I'd get shanked [stabbed] soon as I went out the door. (R: 10, 12 June 2018)

All this supports the notion that the recent rise in gun- and knife-related crime cannot be seen as just a question of reduced police numbers.

In July 2018, the Government announced a doubling of the Early Intervention Youth Fund (Gov.uk. 2018). This is intended to keep young people away from violence, and the London Mayor also announced a rise in the precept for London Policing in April 2018, to enable the deployment of an enhanced force of 120 officers to tackle the problem of gun and knife crime in the capital. This larger force will have greater powers to stop and search (BBC News 2018d). It is also of interest that in interview, the Mayor specifically cites cuts to both policing and local youth services as contributory factors in the recent spike in violent crime. This view could represent an ideological opposition to cuts in public sector provision but his concerns are also echoed by Met. Police Commissioner, the Association of Police and Crime Commissioners (APCC), Lumsden and Black (2017), Her Majesty's Inspector of Constabulary (HMIC) and additionally all respondents involved with this research. It would appear therefore that anxieties about cuts to police numbers are not merely the partisan concern of one political party. As one respondent stated in respect of the police response to local crime:

Why should I worry about them? [the police]. They don't worry me no more.

(R: 10, 12 June 2018)

\section{Government policy of austerity and local authorities}

With regard to the loss of youth and support services for young people, it is important to assess the perceptions of such losses. Since the Coalition Government of 2010 and the subsequent Conservative Government, a succession of policy changes has impacted the provision of public services at local level (UNISON 2018a, b; Buck 2018; Emerson 2017; Hastings et al. 2015) entirely negatively. Respondents alluded to aspects of government policy change over 8 years especially to the effects of cuts to local services. Services referred to in the interviews were cuts to youth services, community support workers, community centres, probation, policing, housing and housing staff plus benefits changes. These concerns have been echoed in the LGiU report (LGiU 2018). Cuts to public spending were and are part of the overall Coalition, then Conservative strategy of Austerity following the financial crash of 2008 (Roberts 2018). The Local Government Association highlighted their concerns in 2014 where they warned that statutory services could not be maintained in the face of large scale cuts to public services (LGA 2014). The majority of the cuts to public spending under Austerity have fallen upon local government in the first instance (JRF 2015) along with major services including the NHS and police service.

3 and 4 . Housing and cuts to youth services 
As part of the policy of Austerity introduced by the Government (Eichler 2018; MacLeavey 2011), there have been cuts to youth service provision in local authority areas. Warnings have been made by statutory agencies regarding the loss, particularly in big cities, of youth provision in local areas. The LGA has warned of the dangers of cutting Youth Offending Teams, sited with local authorities, who provide support to young offenders. Richard Watts, chair of the LGA's Children and Young People's Board argued that:

Increases in knife crime amongst young people highlights the challenge still facing Youth Offending Teams, and we're worried that cutting back on funding risks undermining the progress that's been made over the last decade. (Cited in Eichler 2018).

It is not only the YOTs that have experienced cuts over the last eight years. In 2018 UNISON published a report warning that cutting youth services will inevitably lead to a rise in youth crime. The report argues that deprivation has affected children under the age of 18 more seriously than others. It noted:

It is clear that deprivation is far more acute among young people. And yet it is this group which has borne the brunt of the government's austerity agenda, with the Education Maintenance Allowance cut, higher education tuition fees trebled to $£ 9,000$, and housing benefit slashed. (UNISON 2018a, b, p. 3)

This encompasses many of the issues raised by most of the respondents interviewed. One result is that access to further and higher education is seen as difficult, if not impossible for many young people. Respondent 10 drew attention to what he described as a "hostile" educational environment in London. He stated that:

They don't want us here, like. Black kids and school don't go.

Yet education remains a key element in helping young people focus attention away from crime to a more positive future. The lack of education is, however, part of an overall picture of deprivation and social exclusion.

Social media also appears to be a part of the deprivation paradigm experienced by many young people and is at the heart of the current rise in gun and knife crime. Respondents affirmed that they feel "pushed out" especially in London. Respondent 13 stated that young people in deprived areas and those involved in gangs felt that there was no hope, "It's like impossible. No one can help me. They never have" and no chance of getting out the cycle of deprivation. Respondent 10 stated that:

I can't afford no room. I sleep on the floor at my mums when she let me. I got four brothers and we live in a flat. I can't get no room because I've got a [police] record. I can't pay for it with no job, and anyway, the council can force me to take private [rentals] I can't afford, then when I can't pay, the landlord throws me out and I'm homeless again. (R: 10, 12 June 2018)

Yet Respondent 10 also made clear that he can go home with a pocketful of cash from committing crimes and he can pay his mother and buy what he needs. He cannot find work because he has a criminal record and cannot afford a room in a house 
or flat. The attraction, therefore, for young people in this situation can be seen in such criminal activity as County Lines (Coomber and Moyle 2017, p. 2; Children's Society 2018; NCA 2017) where underage children are being sent by gangs in cities to the regions to transport and sell drugs. Here the "line" refers to the mobile phone line used to connect provincial dealing with the city "hubs" (Coomber and Moyle 2017, p. 2). Respondents 5, 10 and 13 confirmed that County Lines are operated by gangs working together to make money and that for the children involved, this is seen as easy money. David Lammy, MP for Tottenham (BBC Radio 4 on 5 April 2018) has warned that the drugs market is so prolific and easy to access for children that it is as quick to order them as it is to order a pizza (BBC Radio 4, 2018).

This ease of access and the proliferation of County Lines present the evidence of the widespread availability of drugs to children and young people in both cities and the provinces. In the Community Conversation, participants confirmed that County Lines is a major problem locally. "Cuckooing' also occurs in many areas. Here vulnerable people are targeted by those dealing drugs. They are befriended and the dealers then occupy the vulnerable person's accommodation to use as a base from which drugs are made available locally, increasing access to drugs for young people and local addicts" (Coomber and Moyle 2017, p. 3).

For many youngsters involved in County Lines, Cuckooing or other criminal activity, achieving a stable home life is seen as impossible. Moreover, single lone men are not seen as a priority for housing. Changes to housing policy since 2010 mean that Interviews 10 and 13 and others like them are unable to access accommodation via Universal Credit. As he had a criminal record, private landlords were refusing one respondent accommodation, even if he had the money. As Respondent 5 stated:

Just give them somewhere decent to live right? Keep them safe and off the streets. Give them prospects, places to go where they aren't in danger. Look, right, if the local place for kids to meet is the underpass, why are we surprised they get up to stuff? (R: 5, 2 June 2018)

Respondent 11 argued:

...the housing! Have you seen inside these estates? They're so overcrowded and the accommodation is like unhealthy. They've got nowhere nice to live and nowhere to feel safe, some of them. (R: 11, 20 June 2018)

Additionally, if people are single and rent from a private landlord, there are restrictions on how much housing benefit an individual can claim under the age of 35 (Shelter 2018). Support is only provided for a room in a shared house. In 2015, Tunstall warned that the government's policy on housing had resulted in

setting housing association rents above traditional 'social rent' levels, undertaking social housing development without public subsidy, ending the assump- 
tion of security of tenure for council tenants and setting housing benefit at subcost levels, leaving tenants with 'shortfalls' (p. 5).

Therefore, lone young people seeking work may still be unable to afford the rent, even with welfare benefits. Accessing housing is now a serious issue for young people in London and elsewhere when trying to establish themselves in work or education.

George Osborne, when Chancellor, announced in 2015 the removal of entitlement to the housing element of Universal Credit (UC) for 18-21-year-olds from 2017. This was subsequently amended when it was announced that young people aged 18-21 would be able to apply for support for housing as part of UC, but no implementation date was identified (Wilson et al. 2018, p. 3). Respondents 3, 4, 5, 9 and 13 documented strong feelings of resentment among young people over housing problems, the lack of youth services and also bitterness about the affordability of housing. This, they said, suggested that they are being deliberately "pushed out" of London, away from their friends and family. Respondents 4, 5, 6 and 13 commented that this felt like "ethnic cleansing". It suggested that poverty, deprivation and membership of gangs seem to be treated as "markers" for displacing young people.

These were the feelings recorded by the young people themselves and those involved in providing services for them. These are the effects of current government policy. Respondent 4 commented:

These kids have been abandoned by us since the cuts. They're left to themselves in homes where there is usually one parent struggling to cope with overcrowded accommodation and deprivation. Why are we surprised when this happens? [increased gun and knife crime] when we have taken support mechanisms away from them? (R: 4, 14 May 2018)

Prison officers affirmed these feelings by commenting that:

It's like ethnic cleansing you know? If you're a black kid and you come from the Badlands in London, you know, like forget it. You get housed in like Kent, away from your family and friends, of course you're going to run around the streets] rather than get shipped out of London. (R: 5, 2 June 2018).

John Carnochan, founder of the Scottish Violence Reduction Unit, stated that the way to tackle violence in communities such as this is to:

"start to establish relationships with key people in education, social services, child and adolescent mental health teams, and particularly community groups and then start to share information, to divert, to intervene" (Guardian 2018c). This again supports a view that the best way to achieve a reduction in gun and knife crime is to work together collaboratively in communities, share information and involve different agencies. Most important is the need to involve local people and communities. Respondent 16 affirmed that to achieve cohesive communities that work together to tackle their problems, they must be involved as leaders in any collaborative attempt to resolve the issues.

Linden of the Scottish VRU has suggested (BBC Radio 4, 31 July 2018) that pupil exclusion from the education system could be a contributory factor to feelings 
of social isolation and exclusion in young people. Moreover, the Serious Violence Strategy cites low school performance, bullying, truancy and school exclusion as part of the picture for serious violence and the risk factors involved in predicting it among young people (HM Govt. 2018, p. 37).

\section{Changes to probation and local authority support}

Offending children under the age of 18 are dealt with by Youth Offending Teams (YOT). These are hosted by the local authority. When a young offender is arrested, the YOT will get involved with a view to supporting youngsters. They work with other agencies including the Probation Service, Police, Health, Housing, schools and local charities to tackle some of the complex issues that may accompany a young person involved in crime. As with the rest of the UK public sector, YOTs and youth support services have also been subject to significant cuts. These are identified by the Local Government Association $(2018 \mathrm{a}, \mathrm{b})$ and show that a $£ 9$ million in-year cut was experienced in 2015 with a further 12\% budget cut for 2016/17 (LGA 2018a, b, p. 1). With less resources and the Probation Service itself struggling with privatisation, resources are scarce to support young people at every level.

Robinson et al. 2015 paper considers the changes to the Probation Service under the Coalition Government. The most serious offenders were to be dealt with by experienced Probation staff under the Probation Service, while less serious offenders, including those under the age of 18, would be assigned to private sector staff in a Community Rehabilitation Company or CRC (p. 162). The paper also considers an ethically based "Probation ethos" (p. 163) which may have evolved from its police court missionary roots instituted by the Church of England (Mawby and Worrall 2013, p. 2) whose moral purpose was to redeem or reclaim those convicted of offences related to drunkenness. The enduring culture of rehabilitating or reclaiming offenders demonstrates an allegiance to the idea of service in working with individuals to support and help them. This again emerged in interviews 3, 4, 7 and 11. As stated:

They need support, not continual deprivation and punishment. (R: 4, 14 May 2018).

Respondent 13 referred to the help he has received since leaving prison and mentioned that the Probation Service had not offered him effective help, just a paper certificate stating he had attended all his probation meetings since leaving prison. He commented that:

When I come out of prison, there was like nothing. No help. All this crap about having a work coach. It's like hilarious. I never had nothing. No help. I just wanted someone to tell me how to fill in all the forms, you know, to get a bank account and stuff like that. My probation officer, [she's younger than me] she said to me I'd better get used to the idea of being in shared accommodation until I was well into my thirties. What kind of motivation is that? (R: 10 November 2018) 
Comments from respondents stressed the importance of supporting young people in communities where problems such as violence, deprivation and feelings of isolation and exclusion arise. "They have to feel someone is on their side" (Respondent 4). But changes to the provision of support services in both Probation and the YOTs have meant fewer services available due to the cuts. Respondents 5 and 6 commented that by the time young people arrive in prison for serious crimes it is "probably too late". Early intervention appears to be key in tackling community violence and youth crime. This is also stressed in the Government's Serious Violence Strategy (HM Govt. 2018). Yet this will be problematic without robust, fully funded support services in local areas.

A further issue arose during interviews with respondents 5 and 6 in which prison officers stated that due to privatisation in the prison service, jails now tended to be run for profit. This, they said, resulted in the employment of younger personnel with little life experience who are less expensive to employ than older more experienced prison officers. The officer stated that:

You get these really inexperienced young prison officers with no life experience, shoved into situations where they're guarding someone the same age as them or older and they're just out of their depth. But they're a cheap option. Really experienced prison officers are expensive and now the private sector is involved in prisons, it's not going be run out of charity is it? (R: 6, 4 June 2018)

We got no staff and the ones they're employing now, well they're just kids themselves. They have no life experience and they can't help these guys. Most of the time, they just hope they're not going get bladed or beaten up when they go to a cell. (R: 5, 2 June 2018)

Here in UK prisons, young officers are sent into potentially life-threatening situations to protect or control those barely younger, and sometimes the same age as themselves (see above, Interviews 5 and 6). While many are competent and able to tackle such situations, equally many are not.

\section{How can we tackle this?}

Given the higher profile role of a "multi-strand" (HM Govt. 2018, p. 70) approach to tackling problems of serious violence in communities, it is clear that multi-agency partnerships have a role to play in coordinating and sharing intelligence, as defined by John Carnochan of the Scottish VRU and the Government's Serious Violence Strategy. Yet with reduced resources in local government, many public sector organisations are struggling to support partnership working even though these agencies can exchange information about areas of concern which have come to the attention of various services. One example was that of a young person had sought medical attention at the local hospital. As part of the joint conversation, personnel from other agencies such as Social and Caring Services, Housing and Community Safety were able to share intelligence about this young person. 
If I can't share what I know about local trouble spots with people I know can help, how can we tackle the problems together? (R: 9, 18 September 2018).

Equally important is that communities should help in resolving issues and actually lead initiatives. One community coordinator was to note that:

You can't make the mistakes we've made in the past by asking the professionals what community problems there are. You have to ask those people involved, the communities themselves about the issues and what their ideas are to help resolve them. We do that so much in public services: think that we know best, but in this instance, it's the communities that know what works and what doesn't. (R: 17, 14 November 2018).

Despite acknowledged weaknesses in partnership working, the need for a multistrand approach has been strongly recommended in the Government's latest Serious Violence Strategy and endorsed by others (Mawby 2011, pp. 79-80). Shared information between both statutory agencies and local people can materially help to support the police and community safety professionals to prevent violence. The pioneering public health approach of the VRU has shown this to be an effective means to addressing the issue (VRU 2018).

Yet a question remains: How can we jointly act to address the underlying issues of poverty, social exclusion, hopelessness, housing problems, isolation, unemployment and the loss of local services to support young people in cities such as London? During the interview with Linden, a question was asked about how long it would take to effect lasting change in communities affected by serious violence. He stated that:

A generation. We started in 2005 and we are still nowhere near the impact we wanted to have. It's about changing the culture and that is a long, long process. What you can't do is abandon the current generation. If we are looking for some impact now, there's only one answer to that. That's money and resources. We have to at least kick start the process. (R: 15, 12 November 2018)

Working to bring about sustainable change among embedded cultures is a long-term project. The problem of violence in communities is highly complex involving, as identified earlier many factors. Asked if he could identify one factor about the violence, the Pentonville prison officer stated:

No, there's too much happening. Housing is problem, that's for sure. Support for them in the community, that's another one, but it can't ever be brought down to one thing. These killings, they're complicated. It's not Drill, it's not social media, it's everything: everything that's happened to them since 2010 and everything they've lost. (R: 5, 2 June 2018)

It remains the case that addressing the underlying issues of poverty and the loss of local services to support young people in our cities is crucial. Concerted, multistrand action must be taken by both agencies and local people. The Government's Serious Violence Strategy states that tackling serious violence "depends on partnership across a number of sectors such as education, health, social services, 
housing, youth services and victim services" (HM Govt. 2018, p. 7). This list of partners reflects partnerships including community safety partnerships (CSPs) and the remaining Local Strategic Partnerships (Roberts 2016). However, they must include local people. There is a recognition that the problem of gun and knife crime among the young is a complex issue with many contributory factors. Yet partnership approaches require significant support and funding. At a time when cuts to local services are at their most severe, support for partnership working is concomitantly at its most vulnerable (LGA 2018a, b). However, as respondent 15 stated above, we should not abandon the current generation. The answer to making an impact now is surely in resources and yet the evidence shows that there remains a crisis of resources. Without greater support from central and local government, it is difficult to see how multi-agency partnership working alone can effectively tackle this increase in community violence. Lack of resources means that partnerships can only address minor facets of the violence. If we are to make any significant impression on the current problems with gun and knife crime, adequate funding is essential and the involvement of communities vital. This would go beyond policing and extend to undertaking support for communities and local people, youth work, education, housing and health.

Policy change is clearly needed. It remains to be seen whether this could be undertaken in time to stem the surge in violent crime. Working together is at the heart of the drive to resolve the issue of gun and knife crime, but this is not the only strand. Policy in the form of public spending must be addressed by central Government so that the chain of action against the violence is completed.

The United Nation's special rapporteur on extreme poverty and human rights produced a report on poverty in Britain (UN 2018) in which it was stated that:

In the past two weeks I have talked with people who depend on food banks and charities for their next meal, who are sleeping on friends' couches because they are homeless and don't have a safe place for their children to sleep, who have sold sex for money or shelter, children who are growing up in poverty unsure of their future, young people who feel gangs are the only way out of destitution. (p. 1)

From the evidence presented here, it is clear that young people do indeed feel a sense of hopelessness and despair. They feel that gang membership is the only way out of their situation. Being part of a gang gives young people a sense of belonging in an environment where they have felt isolated. But it must be stated that this is not a personal preference. All the young people interviewed did not want the life they were living. They wanted things such as a decent house and car, a job, a wife or husband and family. These are not unusual but mundane desires for many people. Yet the extreme complexity of the community and societal problems in London and other cities must be the focus over the next decade so that the violence of 2018 becomes part of history and not our future.

Acknowledgements The author thanks Barry Loveday for his support and professional, critical eye. 
Open Access This article is distributed under the terms of the Creative Commons Attribution 4.0 International License (http://creativecommons.org/licenses/by/4.0/), which permits unrestricted use, distribution, and reproduction in any medium, provided you give appropriate credit to the original author(s) and the source, provide a link to the Creative Commons license, and indicate if changes were made.

\section{References}

Association of Police and Crime Commissioners. 2015. Budget Cuts Will Radically Affect Policing. http://www.acpccs.police.uk/latest-news/budget-cuts-will-radically-change-policing/. Accessed 31 May 2018.

Balloch, S., and M. Taylor. 2001. Partnership Working: Policy and Practice. Bristol: Policy Press.

BBC. 2018a. Victoria Derbyshire, Kevin Campbell and London Gangs. From Minute 47, April 42018. https://www.bbc.co.uk/iplayer/episode/b09y292b/victoria-derbyshire-04042018.

BBC. 2018b. Victoria Derbyshire. Kevin Campbell London Gangs. Minutes 47.15, 4 April 2018. https:// www.bbc.co.uk/iplayer/episode/bo9y292b/victoria-derbyshire-04042018.

BBC News. 2018a. The Police Team Targeting London's Knife Crime, 22 November 2018. https://www. bbc.co.uk/news/uk-46296640. Accessed 22 Nov 2018.

BBC News. 2018b. London Violence: Concerns Over Crime Reduction Plan, 13 December 2018. https:// www.bbc.co.uk/news/uk-england-london-46538457. Accessed 16 December 2018.

BBC News. 2018c. https://www.bbc.co.uk/news/uk-43603080-Cressida-Dick-Social-media, 31 March 2018. Accessed 13 June 2018.

BBC News. 2018d. https://www.bbc.co.uk/news/uk-england-london-43678988. Accessed 26 July 2018.

BBC News. 2018e. https://www.bbc.co.uk/news/uk-44973258, 27 July 2018. Accessed 1 Aug 2018.

BBC News. 2018f. https://www.bbc.co.uk/news/uk-england-london-45575361, 21 September 2018. Accessed 23 Jan 2018.

BBC Radio 4 Today Programme. 2018. David Lammy MP on Drugs Market in London, 5 April 2018. https://twitter.com/bbcr4today/status/981827189065814016. Accessed 25 July 2018.

Buck, D. 2018. Local Government Spending on Public Health: Death by a Thousand Cuts. [Blog post] The Kings Fund. https://www.kingsfund.org.uk/blog/2018/01/local-government-spending-publi c-health-cuts. Accessed 18 June 2018.

Children's Society. 2018. What is County Lines? https://www.childrenssociety.org.uk/what-is-count y-lines. Accessed 19 June 2018.

Cohen, L. 2017. Communities Can Prevent Violence. [Blog Post] LSE. Retrieved from https://blog.oup. com/2017/12/communities-can-prevent-violence/. Accessed 18 Dec 2018.

Comptroller and Auditor General. 2001. Financial Sustainability of Police Forces in England and Wales. London: Home Office.

Coomber, R., and L. Moyle. 2017. The Changing Shape of Street Level Heroin and Crack Supply in England: Commuting, Holidaying and Cuckooing Drug Dealer Across 'County Lines'. Oxford: Oxford University Press on behalf of the Centre for Crime and Justice Studies.

Cresswell, J.W. 2014. A Concise Introduction to Mixed Methods Research. London: Sage.

Disney, R., and P. Simpson. 2017. Briefing paper BN208 Police Workforce and Funding in England and Wales. London: Institute for Fiscal Studies.

Eichler, W. 2018. Cuts to Youth Services Lead to Rise in Crime, Warn Councils. LocalGov. https://www. localgov.co.uk/Cuts-to-youth-services-lead-to-rise-in-crime-warn-councils/44850. Accessed 18 June 2018.

Emerson, D. 2017. Two Parliaments of Pain: The UK Public Finances 2010-2017. London: Briefing Note, Institute for Fiscal Studies.

Fussey, P., and A. Richards. 2008. Researching and Understanding Terrorism: A Role for Criminology? Criminal Justice Matters 73(1): 37-39. https://doi.org/10.1080/09627250802277041.

Gov.uk. 2018. Early Intervention Youth Fund. https://www.gov.uk/government/news/home-secretarylaunches-and-doubles-the-early-intervention-youth-fund. Accessed 7 August 2018.

Hampshire Police Federation. 2011. http://www.hampshirepolfed.org.uk/cuts_have-consequences/. Accessed 18 June 2018.

Hastings, A., N. Bailey, G. Bramely, M. Gannon, and D. Watkins. 2015. The Cost of the Cuts: The Impact on Local Government and Poorer Communities. Universities of Glasgow and Herriott-Watt for the 
Joseph Rowntree Foundation. https://www.jrf.org.uk/sites/default/files/jrf/migrated/files/SummaryFinal.pdf. Accessed 18 June 2018.

Hood, C. 1991. A Public Management for All Seasons? Public Administration 69(1): 3-19.

H.M. Government. 2000. Local Government Act, 2000. https://www.legislation.gov.uk.ukpga/2000/22/ contents. Accessed 26 July 2018.

HM Government. 2012. House of Commons Home Affairs Committee. Roots of Violent Radicalisation. Nineteenth Report of Session 2010-2012 Volume 1. https://publications.parliament.uk/pa/cm201 012/cmselect/cmhaff/1446/1446.pdf.

H.M. Government. 2018. Serious Violence Strategy. https://www.gov.uk/government/publications/serio us-violence-strategy. Accessed 21 June 2018.

House of Commons Library. 2018. Debate Pack Number CDP-2018-0082, 27 March. https://researchbr iefings.parliament.uk/ResearchBriefing/Summary/CDP-2018-0082\#fullreport. Accessed 23 May 2018.

Hughes, O.E. 2018. Public Management and Administration: An Introduction. London: Macmillan Education, Palgrave.

Independent. 2018. Sadiq Khan to 'Significantly Increase' Stop and Search in London, January 2018. https://www.independent.co.uk/news/uk/crime/sadiq-khan-stop-search-london-crime-plan-violencepolice-metropolitan-stabbings-acid-murder-moped-a8152371.html. Accessed Jan 2019.

Institute for Government. 2017. Performance Tracker. https://www.instituteforgovernment.org.uk/publi cation/performance-tracker-autumn-2017/law-and-order/police. Accessed 20 June 2018.

Joseph Rowntree Foundation, (JRF). 2015. https://www.jrf.org.uk/press/most-deprived-areas-have-borne -brunt-local-government-budget-cuts. Accessed 19 June 2018.

Local Government Association. 2014. How Councils are Planning for Future Cuts. London: LGA.

Local Government Association. 2018a. Cuts to Youth Offending Budgets Putting Crime Reduction Work at Risk. https://www.local.gov.uk/about/news/cuts-youth-offending-budget-putting-crime-reductionwork-risk. Accessed 19 June 2018.

Local Government Association. 2018b. Local Services Face Further £1.3 Billion Government Funding Cut in 2019/2020. https://www.local.gov.uk/about/news/local-services-face-further-ps13-billiongovernment-funding-cut-201920. Accessed 22 Jan 2019.

Local Government Information Unit (LGiU). 2018. The State of Local Government Finance Survey 2018. LGiU. https://www.lgiu.org.uk/wp-content/uploads/2018/02/LGiU-MJ-State-of-Local-Government -Finance-Survey-2018-Full-Report.pdf. Accessed 19 June 2018.

Loveday, B., and R. Smith. 2015. A critical evaluation of current and future roles of police community support officers and neighbourhood wardens within the Metropolitan Police Service and London boroughs: Utilising 'low-cost high-value' support services in a period of financial austerity. International Journal of Police and Science Management 17(2): 74-80. https://doi.org/10.1177/14613 55715580913.

Loveday, B. 2017a. The Shape of Things to Come: An evaluation of fraud and cybercrime as a new crime type and its potential impact on the organisational profile of police services in England and Wales. Policing. https://doi.org/10.1093/police/pax040.

Loveday, B. 2017b. Still plodding along? The police response to the changing profile of crime in England and Wales. International Journal of Police Science and Management 19(2): 101-109.

Lumsden, K., and A. Black. 2017. Austerity policing, emotional labour and the boundaries of police work: An ethnography of a police force control room in England. British Journal of Criminology 58(3): 606-623.

MacLeavey, J. 2011. A 'new politics' of austerity, workfare and gender? The UK coalition government's welfare reform proposals. Cambridge Journal of Regions, Economy and Society 4(3): 355-367.

Mawby, R.C. 2011. 'They were very threatening about do-gooding bastards': Probation's changing relationships with the police and prison services in England and Wales. European Journal of Probation 3(3): 78-94.

Mawby, R.C., and A. Worrall. 2013. Doing probation work: Identity in a criminal justice occupation. Abingdon: Routledge.

Mayors Office. 2018. https://www.london.gov.uk/press-releases/mayoral/stark-reality-of-government -police-funding-cuts. Accessed 18 June 2018.

McVie, S., E. Bates, and R. Pillinger. 2018. Changing patterns of violence in Glasgow and London: Is there evidence of Scottish exceptionalism? LSE. http://blogs.lse.ac.uk/politicsandpolicy/patte rns-of-violence-glasgow-london/?utm_source=feedburner\&utm_medium=email\&utm_campa 
ign=Feed $\% 3 \mathrm{~A}+$ BritishPoliticsAndPolicyAtLse+\%28British+politics+and+policy+at+LSE $\% 29$. Accessed 18 Dec 2018.

National Crime Agency (NCA). 2017. County Lines, Violence, Exploitation and Drug Supply: National Briefing Report (2017). http://www.nationalcrimeagency.gov.uk/publications/832-county-lines-viole nce-exploitation-and-drug-supply-2017/file. Accessed 19 June 2018.

Parliament TV. 2018. Home Affairs Select Committee, Minutes 9.45-9.47, 5 June 2018. https://parli amentlive.tv.Event/Index/f509cba6-db75-472d-885b-985cb5423aa1. Accessed 5 June 2018.

Police Executive Research Forum (PERF). 2018. The Changing Nature of Crime and Criminal Investigations. https://www.policeforum.org/assets/ChangingNatureofCrime.pdf. Accessed 20 Dec 2018.

Pollitt, C. 2003. The Essential Public Manager. Maidenhead: McGraw Hill International.

Roberts, S. 2016. Just Good Friends: Can Localism Succeed Through Partnership? https://researchportal. port.ac.uk/portal/files/5115032/ECPR_paper_version_15_June_1_.pdf. Accessed 3 Jan 2019.

Roberts, S. 2018. Detecting Radicalisation in Communities: The Role of Multi-agency Partnership and the Power of Local Information. http://rais.education/wp-content/uploads/2018/04/April003.pdf. Accessed 12 June 2018.

Robinson, G., L. Burke, and M. Millings. 2015. Criminal Justice Identities in Transition: The Case of Devolved Probation Services in England and Wales. British Journal of Criminology 56(1): 161-178.

Scott, P., and S. Pandey. 2005. Red Tape and Public Service Motivation. Review of Public Personnel Administration 25(2): 155-180.

Shelter. 2018. Housing Benefit for Young People. https://england.shelter.org.uk/housing_advice/benefits/ housing_benefit_for_young_people. Accessed 19 June 2018.

The Guardian. 2017. Scotland Yard Warns of Policing Cuts if Budget Reduces Officer Numbers, October 2017. https://www.theguardian.com/uk-news/2017/oct/30/scotland-yard-warns-of-policing-cuts-ifbudget-reduces-officer-numbers. Accessed 25 June 2018.

The Guardian. 2018a. Met Chief Says Budget Cuts Have Contributed to Rise in Violent Crime. www. theguardian.com/uk-news/2018/may/18/metropolitan-police-cressida-dick-budget-cuts-violentcrime-rise-london. Accessed 28 June 2018.

The Guardian. 2018b. Amber Rudd Says Police Cuts Not to Blame for Violent Crime Rise, April 18 2018. https://www.theguardian.com/politics/2018ape/08/amber-rudd-says-says-police-cuts-not-toblame-for-violent-rise. Accessed 10 June 2018.

The Guardian. 2018c. Treat London's Violence as Public Health Crisis, Say Scottish Experts, April 6 2018. https://www.theguardian.com/uk-news/2018/apr/06/treat-london-violence-as-public-healt h-crisis-say-scottish-experts. Accessed 31 July 2018.

The Guardian. 2019. Knife ASBOs Won't Cut Crime, But the Will Harm Vulnerable Young People. https ://www.theguardian.com/commentisfree/2019/feb/01/knife-asbos-crime-young-people-sajid-javid. Accessed 6 Feb 2019.

Tunstall, R. 2015. The Coalition's Record on Housing: Policy, Spending an Outcomes 2010-2105. Working Paper 18. London: LSE. http://sticerd.lse.ac.uk/dps/case/spcc/WP18.pdf. Accessed 18 June 2018.

UNISON. 2018a. https://www.unison.org.uk/at-work/local-government/key-issues/cuts-to-local-servi ces/. Accessed 18 June 2018.

UNISON. 2018b. The Damage. https://www.unison.org.uk/content/uploads/2014/07/On-line-Catalogue2 25322.pdf. Accessed 3 Jan 2019.

United Nations. 2015. New and Emerging Forms of Crime: Threats the World Must Reckon With. UN Factsheet. http://www.un.org/en/events/crimecongress2015/pdf/Factsheet_5_Emerging_forms_of_ crime_EN.pdf. Accessed 18 June 2018.

Violence Reduction Unit, (VRU). 2018. http://actiononviolence.org/about-us. Accessed 4 Jan 2018.

World Health Organisation (WHO). 2002. Report on Violence and Health: A Summary. Geneva: WHO. http://apps.who.int/iris/bitstream/handle/10665/42495/9241545615_eng.pdf;jsessionid=1A8F2 63F8F26F0B1E987686CEB8A6F2B?sequence=1. Accessed 7 Aug 2018.

Wilson, W., R. Keen, and C. Barton. 2018. The Housing Cost Element of Universal Credit and 18-21 Year Olds. House of Commons Briefing Paper No. 06473. London: House of Commons Library.

Wisker, G. 2007. The Post Graduate Research Handbook: Succeed with your MA, MPhil, EdD and PhD (Palgrave Research Skills). Basingstoke: Palgrave Macmillan. 


\section{Interviews}

Interview 1: Serving PCSO Hampshire Constabulary. 22 April 2018.

Interview 2: Serving police commander, Hampshire Constabulary 24 April 2018.

Interview 3: Youth worker, Portsmouth. 13 May 2018.

Interview 4: Local Charity support work and former Probation officer, 14 May 2018.

Interview 5: Former Prison Officer, London Pentonville prison. 2 June 2018.

Interview 6: Former Prison Officer, Belmarsh prison, 4 June 2018.

Interview 7: Serving Youth Worker London Borough of Hackney, 18 August 2018.

Interview 8: Serving police officer, London Metropolitan Police, 12 June 2018.

Interview 9: Local Authority Community Safety Officer, 18 September 2018.

Interview 10: Former gang member inner London, 12 June 2018.

Interview 11: Youth worker Croydon. 20th June 2018.

Interview 12: Police Inspector Surrey Police, 8 April 2018.

Interview 13: Former prisoner and drugs dealer. 9 November 2018.

Interview 14: Group of young people from Croydon. 30 July 2018.

Interview 15: Will Linden, Scottish Violence Reduction Unit. 12 November 2018.

Interview 16: Community Co-ordinator, Portsmouth City Council. 13 November 2018.

Interview 17: Community development officer, London Borough Newham. 14 November 2018.

Publisher's Note Springer Nature remains neutral with regard to jurisdictional claims in published maps and institutional affiliations. 